\title{
Analisis Perubahan Penggunaan Lahan di Kota Pekalongan Tahun 2003, 2009, dan 2016
}

\author{
Ali Wijaya dan Cahyono Susetyo \\ Departemen Perencanaan Wilayah dan Kota, Fakultas Teknik Sipil dan Perencanaan, Institut \\ Teknologi Sepuluh Nopember (ITS) \\ e-mail: c.susetyo@urplan.its.ac.id
}

\begin{abstract}
Abstrak-Kota Pekalongan merupakan salah satu kota di pesisir utara Pulau Jawa yang rentan terhadap banjir rob. Banjir rob tersebut sebagai faktor pemicu perubahan penggunaan lahan dan telah berdampak besar pada penggunaan lahan yang ada terutama pada lahan produktif. Untuk itu diperlukan suatu analisis terkait penggunaan lahan sesuai dengan dinamika di wilayah tersebut. Tujuan penelitian ini dapat dicapai dengan dua tahapan penelitian. Tahap pertama yaitu mengklasifikasi penggunaan lahan dari citra Quickbird di Kota Pekalongan. Tahap kedua yaitu menganalisis perubahan penggunaan lahan di Kota Pekalongan menggunakan analisis overlay secara multi temporal periode tahun 2003, 2009, dan 2016. Hasil penelitian ini menunjukkan bahwa penggunaan lahan pada wilayah penelitian hingga tahun 2016 didominasi oleh lahan permukiman , rawa, dan lahan pertanian. Kenaikan muka air laut berdampak paling besar terhadap penggunaan lahan pertanian yang mengalami pengurangan luas sebesar $370.26 \mathrm{Ha}$ dan penambahan luas rawa sebesar 292.68 Ha pada periode tahun 2003 hingga 2016.
\end{abstract}

Kata Kunci-Geographic Information System, Kota Pekalongan, Overlay, Penggunaan Lahan.

\section{PENDAHULUAN}

$S_{\text {pessen }}^{\mathrm{E}}$ ETIAP wilayah tidak bisa lepas dari lahan dan penggunaannya yang merupakan suatu hal yang dinamis. Salah satu karakteristik proses perkembangan suatu wilayah dan kota adalah adanya perubahan penggunaan lahan. Perubahan penggunaan lahan dipicu oleh berbagai faktor yang saling berinteraksi satu sama lain yang disebut dengan istilah driving force. Setiap bentuk perubahan penggunaan lahan pada suatu bidang tertentu akan berpotensi mempengaruhi penggunaan lahan lain didekatnya [1]. Penggunaan model analisis dari perubahan penggunaan lahan dan pertumbuhan perkotaan dapat menjadi sarana penting dalam mendukung perencanaan dan manajemen perkotaan [2], [3].

Kota Pekalongan merupakan salah satu kota di Jawa Tengah yang berada di pesisir utara Pulau Jawa yang seringkali mengalami banjir rob akibat kenaikan muka air laut. Terdampaknya Kota Pekalongan dari kenaikan muka air laut berpengaruh pada karakteristik perkembangan kotanya. Adanya banjir rob tersebut menyebabkan dampak yang besar pada penggunaan lahan produktif yang ada [4], yaitu menjadi salah satu pemicu perubahan penggunaan lahan di Kota Pekalongan akibat tergenang oleh kenaikan muka air laut [5].

Berdasarkan data statistik, di Kota Pekalongan luas lahan sawah setiap tahunnya selalu berkurang. Pada tahun 2014, luas tanah sawah mengalami pengurangan sekitar 8 persen dari tahun sebelumnya [6]. Selain lahan pertanian, lahan tambak juga mengalami perubahan akibat terdampak genangan kenaikan muka air laut. Berdasarkan pendataan dari Dinas Kelautan dan Perikanan Kota Pekalongan, pada tahun 2015 lahan tambak yang tidak dapat digunakan (idle) mencapai 346 Ha. Lahan budidaya tambak tersebut menjadi tidak produktif akibat tingginya genangan dari kenaikan muka air laut yang terjadi. Kemudian secara keseluruhan untuk perubahan penggunaan lahan yang telah terjadi di Kota Pekalongan dalam periode waktu tahun 2003 sampai tahun 2009 sudah banyak mengalami perubahan pemanfaatan dikarenakan salah satu faktornya adalah adanya banjir rob [7]. Kondisi tersebut tentunya akan mengakibatkan terbentuknya pola penyebaran penggunaan lahan yang tidak optimal.

Jika dikaitkan dengan kecenderungan perubahan iklim, dampak kenaikan muka air laut terhadap Kota Pekalongan akan semakin bertambah [4], [8] dan perubahan penggunaan lahannya akan semakin besar. Sebagaimana diketahui bahwa banjir rob akibat kenaikan muka air laut tidak bisa dihilangkan, akan tetapi hanya dapat direduksi dampaknya [9] termasuk dampak terhadap penggunaan lahan. Ketepatan penggunaan lahan dan manajemennya di Kota Pekalongan merupakan suatu hal yang penting dalam proses perencanaan [10] untuk meminimalisir dampak dari bencana seperti banjir rob yang diprediksikan akan terus mengalami peningkatan di setiap tahunnya [11].

Oleh karena hal tersebut, diperlukan suatu analisis terkait perubahan penggunaan lahan di Kota Pekalongan dengan pendekatan spasial yang tepat untuk mengetahui dan mengoptimalkan perkembangan di wilayah Kota Pekalongan. Maka, rumusan masalah yang diangkat adalah bagaimana kecenderungan perubahan penggunaan lahan di Kota Pekalongan. Untuk menjawab rumusan masalah tersebut, penelitian ini berupaya untuk menganalisis perubahan penggunaan lahan secara spasial dengan dimensi multi temporal menggunakan Geographic Information System.

\section{METODE PENELITIAN}

\section{A. Metode Pengumpulan Data}

Data yang digunakan pada penelitian ini terdiri atas data primer dan sekunder, dimana data primer diperoleh berdasarkan survei primer dan observasi lapangan untuk validasi peta penggunaan lahan serta mendapatkan gambaran 
kondisi lapangan. Sedangkan data sekunder diperoleh dari citra satelit, penelitian terdahulu, dan dokumen-dokumen instansi terkait.

\section{B. Metode Analisis}

Tahapan analisis dalam penelitian ini antara lain terdiri dari klasifikasi penggunaan lahan dan analisis perubahan penggunaan lahan. Analisis yang dilakukan merupakan analisis berbasis Geographic Information System (GIS) sesuai dengan kebutuhan penelitian dalam segi spasial.

\section{Klasifikasi Penggunaan Lahan}

Tahapan pertama dalam penelitian ini adalah mengklasifikasikanpenggunaan lahan di Kota Pekalongan. Dalam proses ini dibutuhkan penggunaan lahan dalam beberapa penggunaan lahan dalam dimensi waktu yang berbeda (multi temporal). Penelitian ini menggunakan penggunaan lahan pada tahun 2003, 2009, dan 2016 yang didapat dari interpretasi citra satelit yang kemudian diklasifikasikan untuk penggunaan lahannya. Dalam penelitian ini menggunakan citra Quickbird yang merupakan satelit observasi bumi komersial resolusi tinggi, yang dimiliki oleh DigitalGlobe dan diluncurkan pada tahun 2001.

Citra Quickbird yang telah disetting untuk sistem koordinatnya dapat didelineasi secara manual penggunaan lahannya dengan teknik interpretasi visual berdasarkan karakteristiknya. Unsur-unsur interpretasi yang digunakan mencakup rona, bentuk, tekstur, pola, ukuran, bayangan, situs, dan asosiasi. Dalam interpretasi, dilakukan klasifikasi penggunaan lahan yang tampak pada citra. Di setiap kenampakan karakteristik lahan yang homogen dikategorikan dan didelineasi dengan digitasi pada layar yang kemudian menghasilkan data vector. Dalam penelitian ini klasifikasi penggunaan lahan yang digunakan mengacu pada SNI nomor 7645:2010 tentang penutup lahan, yang kemudian dimodifikasi sesuai dengan karakteristik penggunaan lahan di wilayah penelitian.

Hasil delineasi klasifikasi penggunaan lahan kemudian dilakukan proses validasi dengan pengecekkan lapangan. Dalam proses validasi penelitian ini telah ditentukan 100 titik sampel secara acak dengan spatial sampling yang akan dicek dengan survei lapangan. Survei lapangan dilakukan untuk melengkapi hasil interpretasi citra satelit dan membuktikan kebenaran delineasi dalam klasifikasi penggunaan lahan pada wilayah penelitian sehingga data akhir memiliki keakuratan tinggi. Data penggunaan lahan tahun 2003, 2009, 2016 yang telah dihasilkan dari serangkaian proses kemudian dilanjutkan untuk mengetahui perubahan penggunaan lahan

\section{Analisis Perubahan Penggunaan Lahan}

Analisis perubahan penggunaan lahan dilakukan dengan membandingkan antar peta penggunaan lahan tahun 2003, 2009, dan 2016 yang telah divalidasi dengan menggunakan metode analisis overlay GIS. Analisis overlay (tumpang tindih) adalah salah satu teknik analisis yang dapat dilakukan dengan bantuan software pengolahan data spasial ArcGIS. Teknik analisis overlay dilakukan dengan cara meletakkan sebuah peta beserta seluruh atribut di dalamnya di atas sebuah peta lain untuk kemudian ditampilkan hasilnya.
Hasil dari proses analisis overlay ini adalah peta perubahan penggunaan wilayah penelitian. Peta perubahan penggunaan lahan adalah peta yang menunjukkan distribusi spasial dari lahan yang berubah dan tidak berubah penggunaannya. Selain iyu juga dapat diketahui untuk statistik perubahan penggunaan lahannya setiap periode tahunnya. Perubahan penggunaan yang dihasilkan dalam penelitian ini berupa 3 periode waktu, yaitu periode tahun 2003-2009, tahun 2009-2016, dan tahun 20032016. Dari data perubahan penggunaan lahan ini, dapat diketahui statistik jenis, luasan, distribusi, dan kecenderungan perubahan penggunaan lahan di Kota Pekalongan. Output dari analisis overlay ini akan menjawab tujuan penelitian secara keseluruhan yaitu menganalisis perubahan penggunaan lahan di Kota Pekalongan.

\section{HASIL DAN PEMBAHASAN}

\section{A. Klasifikasi Penggunaan Lahan Kota Pekalongan}

Proses klasifikasi penggunaan lahan dari citra dalam penelitian ini menggunakan digitation on screen dengan GIS. Kenampakan gambar secara visual pada citra dikelompokkan berdasarkan kesamaan untuk menjadi vector kelas penggunaan lahan. Interpretasi menggunakan 6 kunci pengenal citra yaitu warna, bentuk, ukuran, tekstur, bayangan, dan situs. Berikut klasifikasi jenis penggunaan lahan yang digunakan dalam penelitian ini.

Tabel 1.

Klasifikasi Jenis Penggunaan Lahan

\begin{tabular}{cl}
\hline \hline KODE & PENGGUNAAN LAHAN \\
\hline LU 1 & Industri \\
LU 2 & Lahan Terbuka \\
LU 3 & Perdagangan \\
LU 4 & Kebun Campur \\
LU 5 & Permukiman \\
LU 6 & Pertanian \\
LU 7 & Rawa \\
LU 8 & RTH \\
LU 9 & Sungai \\
LU 10 & Tambak \\
LU 11 & Transportasi \\
\hline \hline
\end{tabular}

Setiap jenis penggunaan lahan memiliki karakteristik tertentu yang berbeda dengan jenis penggunaan lahan lainnya. Hasil dari klasifikasi penggunaan lahan yang telah didigitasi di GIS akan menjadi peta penggunaan lahan multi temporal tahun 2003, 2009, dan 2016 sesuai dengan tahun perekaman citra satelit yang digunakan. 


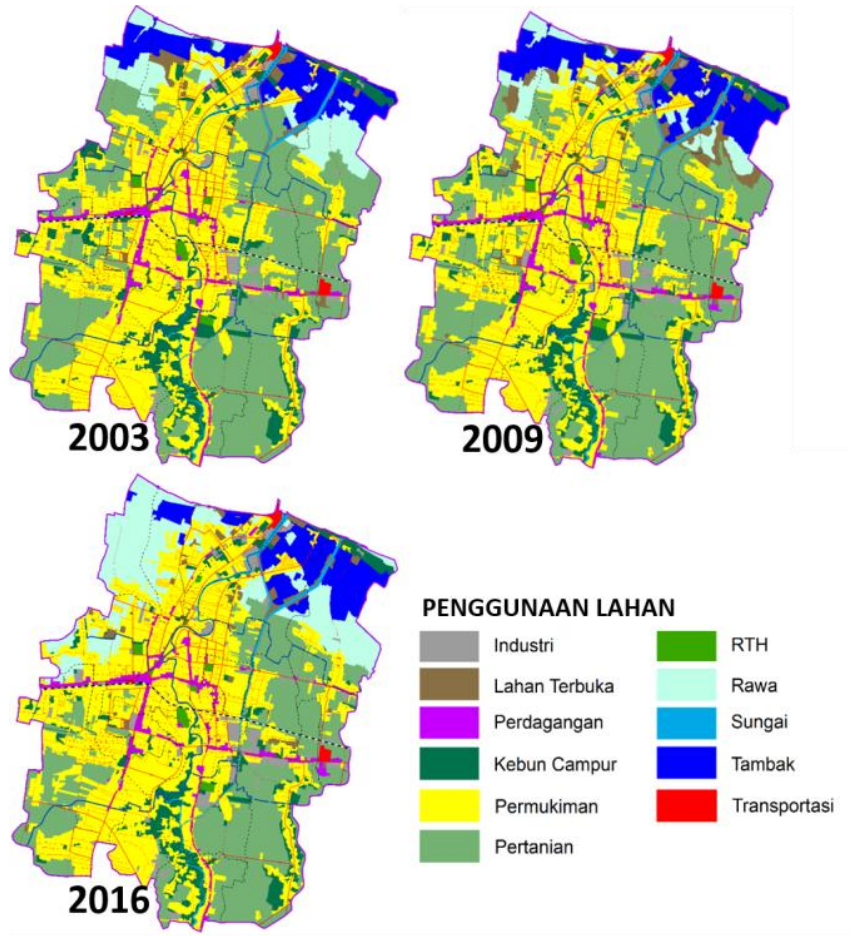

Gambar 1. Peta Penggunaan Lahan Kota Pekalongan.

Kemudian hasil klasifikasi penggunaan lahan di Kota Pekalongan berdasarkan interpretasi visual menggunakan GIS yang telah dihasilkan, dilakukan validasi lapangan agar penggunaan lahan tersebut sesuai dengan kondisi sebenarnya dan memiliki tingkat validitas yang bisa digunakan. Dalam proses validasi dalam penelitian ini menggunakan sampel secara spatial sampling dengan skema random sesuai dengan jenis penggunaan lahannya. Untuk lokasi tiap titik validasinya ditentukan secara acak dan menyebar secara merata untuk jenis penggunaan lahan dan lokasinya. Untuk penggunaan lahan temporal pada tahun 2003 dan 2009, mengadaptasi data penggunaan lahan dari penelitian terdahulu terkait penggunaan lahan di Kota Pekalongan dan menyesuaikan kenampakan dari citra satelit yang diinterpresikan. Persentase akurasi klasifikasi penggunaan lahan dihitung dari perbandingan sampel yang sesuai dengan jumlah sampel. Hasil perhitungan akurasi setiap jenis penggunaan lahan terdapat dalam tabel berikut.

Tabel 2.

Akurasi Klasifikasi Penggunaan Lahan

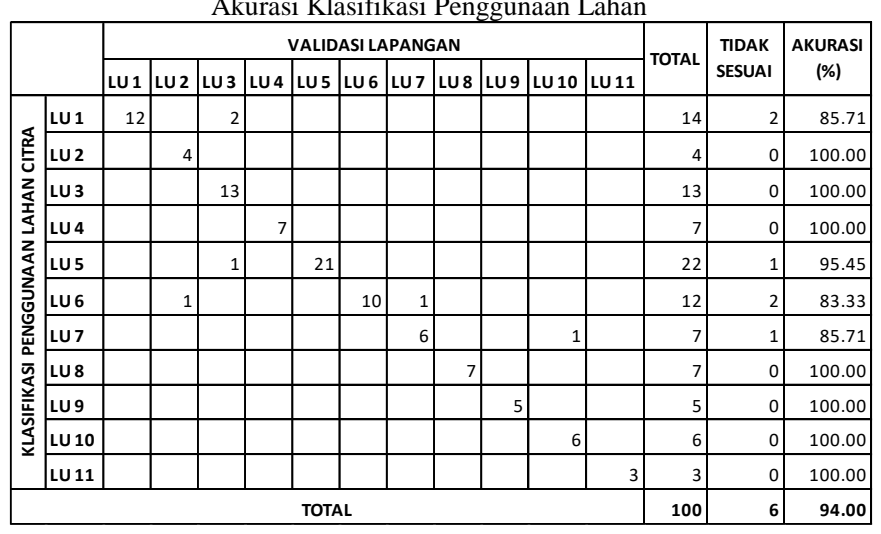

Hasil perhitungan menunjukkan bahwa akurasi dari klasifikasi penggunaan lahan mencapai 94\%, dengan rincian 6 dari 100 sampel yang telah disurvei tidak sesuai dengan hasil validasi lapangan. Dengan nilai akurasi yang tergolong tinggi tersebut, maka hasil klasifikasi penggunaan lahan dapat digunakan untuk analisis selanjutnya.

\section{B. Analisis Perubahan Penggunaan Lahan Kota Pekalongan}

Penggunaan lahan Kota Pekalongan tahun 2003, 2009, dan 2016 yang yang telah divalidasi sebelumnya kemudian dihitung untuk luasan setiap jenis penggunaan lahannya dan dilakukan tumpang tindih (overlay) antar periode waktu (2003, 2009, dan 2016). Overlay antar peta dilakukan menggunakan GIS agar dapat diketahui untuk perubahan penggunaan lahannya. Statistik perubahan penggunaan lahan menunjukkan dinamika dari adanya penggunaan lahan yang ada. Hal tersebut disebabkan oleh adanya driving factor yang mempengaruhi setiap jenis penggunaan lahan yang ada, terutama faktor banjir rob yang terjadi di Kota Pekalongan. Berikut adalah statistik luas penggunaan lahan di Kota Pekalongan berdasarkan penghitungan GIS untuk periode tahun 2003, 2009, dan 2016.

Tabel 3.

Statistik Luas Penggunaan Lahan

\begin{tabular}{clccc}
\hline \hline \multirow{2}{*}{ NO } & $\begin{array}{c}\text { PENGGUNAAN } \\
\text { LAHAN }\end{array}$ & $\mathbf{2 0 0 3}$ & $\mathbf{2 0 0 9}$ & $\mathbf{2 0 1 6}$ \\
\hline 1 & Industri & 103.90 & 120.37 & 146.24 \\
2 & Lahan Terbuka & 66.65 & 137.08 & 66.30 \\
3 & Perdagangan & 117.62 & 127.59 & 135.82 \\
4 & Kebun Campur & 328.10 & 293.29 & 267.91 \\
5 & Permukiman & 1805.93 & 1878.21 & 1977.02 \\
6 & Pertanian & 1582.59 & 1474.27 & 1127.24 \\
7 & Rawa & 252.84 & 163.01 & 545.91 \\
8 & RTH & 27.71 & 27.71 & 27.71 \\
9 & Sungai & 76.62 & 76.62 & 76.62 \\
10 & Tambak & 283.63 & 347.45 & 274.83 \\
11 & Transportasi & 15.41 & 15.41 & 15.41 \\
\hline \hline
\end{tabular}

Dari hasil analisis diatas dapat diketahui untuk dinamika penggunaan lahan di Kota Pekalongan. Setiap jenis penggunaan lahan yang ada mengalami perubahan berupa penambahan luasan atau pengurangan luasan, kecuali untuk jenis penggunaan lahan berupa RTH, sungai, dan transportasi yang statis dan tidak mengalami perubahan di setiap periode tahunnya. Penggunaan lahan terluas di Kota Pekalongan pada tahun 2016 secara berurutan adalah permukiman, pertanian, rawa, dan tambak. Dalam kurun waktu tahun 2003-2016, penggunaan lahan yang paling besar mengalami perubahan luasan antara lain adalah penggunaan lahan pertanian, rawa, dan permukiman. Berikut untuk perbandingan luasan penggunaan lahan di setiap periode tahunnya. 


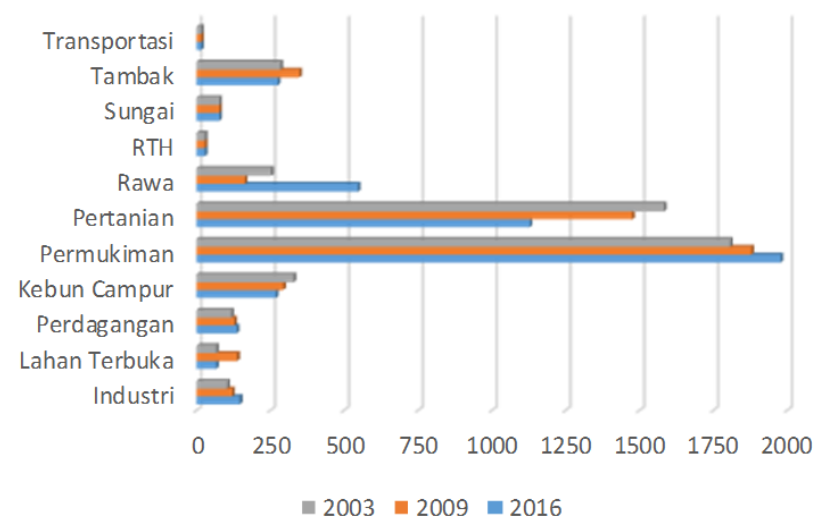

Gambar 2 . Chart Perbandingan Luas Penggunaan Lahan

Penggunaan lahan paling besar di Kota Pekalongan adalah permukiman dengan tren selalu mengalami penambahan luas. Untuk rentang waktu dari tahun 2003 sampai 2016, permukiman di Kota Pekalongan bertambah sebesar 171,08 Ha. Kemudian setelah permukiman, penggunaan lahan terbanyak adalah pertanian. Untuk tren penggunaan lahan pertanian selalu menurun. Dengan kata lain telah terjadi banyak konversi dari lahan pertanian menjadi penggunaan lahan lainnya. Dalam kurun waktu periode tahun 2003 hingga 2016 luas lahan pertanian di Kota Pekalongan berkurang sejumlah $455.36 \mathrm{Ha}$. Untuk selanjutnya penggunaan lahan rawa mengalami penambahan luas paling signifikan dari tahun 2009 sampai dengan 2016 yang mencapai penambahan luas sebesar 382,9 Ha. Besarnya perubahan penggunaan lahan tersebut salah satunya disebabkan oleh adanya dampak genangan dari kenaikan muka air laut di Kota Pekalongan.

\section{KESIMPULAN/RINGKASAN}

Berdasarkan hasil dari keseluruhan proses terkait tujuan utama penelitian, maka dapat ditarik kesimpulan sebagai berikut:

1. Kota pekalongan memiliki perubahan penggunaan lahan yang besar, Dalam kurun waktu tahun 2003-2016, penggunaan lahan di Kota Pekalongan yang paling banyak mengalami perubahan luasan adalah penggunaan lahan pertanian, rawa, dan permukiman. Lahan pertanian, selalu mengalami pengurangan luasan yang signifikan, dalam periode 2003 hingga 2016 berkurang sebesar 455,36 Ha. Sedangkan rawa mengalami perluasan yang sangat signifikan pada periode 2009 ke 2016 seluas 382.90 Ha..

2. Sebagai rekomendasi, diperlukan manajemen penggunaan lahan seperti pengendalian akan pengembangan lahan terbangun antara lain dengan membatasi pertumbuhan lahan seperti permukiman, industri, dan perdagangan terutama pada wilayah terdampak kenaikan muka air laut.

\section{UCAPAN TERIMA KASIH}

Terima kasih disampaikan kepada berbagai pihak terkait yang telah membantu terutama kepada Direktorat Jenderal Pembelajaran dan Kemahasiswaan, Kementrian Riset, Teknologi dan Pendidikan Tinggi Republik Indonesia yang telah diterimanya dalam kegiatan Program Kreativitas Mahasiswa Bidang Penelitian 2017 sebagai salah satu kegiatan pengembangan penelitian ini.

\section{DAFTAR PUSTAKA}

[1] G. A. Rahadyan and P. G. Ariastita, "Skenario Pengembangan Lahan Permukiman Pasca Terbangunnya Interchange Jalan TOL Mojokerto-Kertosono di Kawasan Perkotaan Bandar Kedungmulyo Kabupaten Jombang,” J. Tek. ITS, vol. 4, no. 1, 2015.

[2] E. J. Gustafson, "Minireview: Quantifying Landscape Spatial Pattern: What Is the State of the Art?," Ecosystems, vol. 1, no. 2, pp. 143-156, 1998.

[3] M. Herold, H. Couclelis, and K. C. Clarke, "The Role of Spatial Metrics In The Analysis and Modeling of Urban Land Use Change," Comput. Environ. Urban Syst., vol. 29, no. 4, pp. 369399, 2003.

[4] M. A. Marfai, D. Mardianto, A. Cahyadi, F. Nucifera, and H. Prihatno, "Pemodelan Spasial Bahaya Banjir Rob Berdasarkan Skenario Perubahan Iklim dan Dampaknya di Pesisir Pekalongan," J. Bumi Lestari, vol. 13, no. 2, pp. 244-256, 2013.

[5] R. Shofiana, P. Subardjo, and I. Pratikto, "Analisis Perubahan Penggunaan Lahan di Wilayah Pesisir Kota Pekalongan Menggunakan Landsat 7 ETM+," J. Mar. Res., vol. 2, no. 3, pp. 35-43, 2013.

[6] BPS Kota Pekalongan, Kota Pekalongan Dalam Angka 2016. Pekalongan, 2016.

[7] N. A. Pratomoatmojo, "Land Use Change Modelling Under Tidal Flood Scenario by Means of Markov Cellular Automata in Pekalongan Municipal," Universitas Gadjah Mada, 2012.

[8] G. Chust et al., "Human Impacts Overwhelm The Effects of Sea Level Rise on Basque Coastal Habitats (N Spain) Between 1954 and 2004," Estuar. Coast. Shelf Sci., vol. 84, no. 4, pp. 453-462, 2009.

[9] Diez et al, "Urban Coastal Flooding and Climate Change," J. Coast. Res, vol. SI 64, pp. 205-209, 2011.

[10] H. S. Yunus, Manajemen Kota Dari Perspektif Spasial. Yogyakarta, 2005.

[11] S. Nashrrullah, Aprijanto, J. M. Pasaribu, M. K. Hazarika, and L. Samarakoon, "Study on Flood Inundation in Pekalongan, Central Java," Int. J. Remote Sens. Earth Sci., vol. 10, no. 2, pp. 76-83, 2013. 